\title{
Does trade liberalization always decrease union bargaining power?
}

Jorge Saba Arbache*

Thetheoretical and empirical literature shows that union wages are more responsive to international import competition than nonunion wages, thus reducing unions bargaining power. In this paper we track the influence of unions on wages in Brazil before and after the trade liberalization in the beginning of the 1990s. We find that union bargaining power increased rather that decreased after economic openness. 0 ur results seem to be related to the bargaining framew ork prevailing in the Brazilian labor market.

A literatura teórica e empírica mostra que os salários dos trabalhadores sindicalizados são mais sensíveis à competição de bens importados do que os salários dos trabalhadores não sindicalizados, reduzindo o poder de barganha dos sindicatos. Este artigo examina a influência dos sindicatos nos salários no Brasil antes e depois da abertura comercial do início dos anos 1990 e conclui que, de forma geral, o poder de barganha dos sindicatos aumentou ao invés de diminuir após a abertura. Esse resultado parece estar de acordo com a estrutura de barganha col etiva que prevalece no mercado de trabalho brasileiro.

JEL Classification: F16, J31, J51

Keywords: $\quad$ Union, trade liberalization, wage structure, wage dispersion, Brazil

* University of Brasilia. 


\section{Acknowledgments}

I would like to thank Francisco Carneiro, Andy Dickerson, Francis Green, Sarquis B. Sarquis, seminar participants at the University of Brasilia, University of Sao Paulo, EALE/ SOLE 2000 World Conference, Milan, and XXVII ANPEC Meeting, Belém, and two anonymous referees for comments and suggestions on earlier versions of this paper. The usual disclaimer applies. Financial support from the Brazilian Research Council (CNPq) is gratefully acknowledged.

\section{Correspondence address}

Departamento de Economia, Universidade de Brasília, Brasília DF, Caixa Postal 04302, CEP 70910-900, Brazil, Tel: +55 613072498 extension 119; Fax: +55 61340 2311; E-mail: jarbache@unb.br.

\section{Introduction}

The movement towards trade liberalization, deregulation and privatization of State-owned companies in industrializing countries in the 1980s and early 1990s has been possibly the most important and significant changein the labor markets of these countries in recent decades. One way to measure the impact of such reforms is through the analysis of unions' effects on the wage structure. Unfortunately, there has yet to be a comprehensive investigation of this issue tracking unions before and after the implementation of economic reforms for industrializing countries. Evidence on this topic may provide valuable information on how unions react to economic changes, and will improve the understanding on the labor market adjustments in countries experiencing radical economic reforms.

There is a vast literature on the impact of trade, deregulation, and institutional changes on union wages, but it is mainly concerned with developed countries. Gosling and Machin (1995) and Fortin and Lemieux (1997), for example, find that institutional changes in the U.K. and U.S. have decreased the union power and increased earnings inequality due to the unions aim of wage rate standardization. Peoples (1998) shows for 
theU.S. that union bargaining power dedined in three out of four industries following deregulation. Stewart (1991) found that economic and industrial relations legislation changes in the U.K. had littleimpact on union-nonunion wage differentials. Freeman and Katz (1991) identify that union wages are more responsive to international import competition than nonunion wages. MacPherson and Stewart (1990) show that the union nonunion wage gap is lower among industries facing greater import competition. MacPherson and Stewart, and Blumenfeld and Partridge (1996) argue that international competition is an important factor explaining the union decline in the U.S. The last two papers also show that wages respond differently to imports according to industry union density.

In this paper we investigate the influence of unions on wage dispersion and wage structure in Brazil, a country that experienced major economic reforms in the first half of the 1990s. The case of Brazil is particularly interesting because of at least two reasons. First, theintermediatestructure of wage bargaining (in the Cal mfors and Driffill, 1988, classification), which allowed the growth of a strong rent-seeking behavior and strong insider power. ${ }^{1}$ Accordingly, Amadeo $(1993,1994)$ and Carneiro (1999) find that sectoral conditions play an important role in real wage determination in Brazil. As one of the consequences, wage dispersion in the union sector is larger than in the nonunion sector (Arbache, 1999, 2002; Arbache and Carneiro, 1999). However, the union power was suddenly confronted with dramatic changes in the economic environment in the 1990s. This may have threatened the unions' bargaining power and, therefore, their impact

\footnotetext{
${ }^{1}$ In the most centralized and coordinated bargaining systems, wage determination tends to be more sensitive to the general conditions of the labor market, and income distribution tends to be more equal. At the other end of the scale, fragmented bargaining systems that operate at the establishment level tend to be more sensitive to the economic conditions facing the company. In both cases, union demands are tempered by disincentives arising from the effects of inconsistent demands on the workers themselves, such as unemployment, inflation, or a lack of formalization of the employment contract. Calmfors and Driffill (1988) show that collective bargaining organized at the industry level, as in Brazil, is the worst possible structure, because workers have few incentives to incorporate into their objective functions the conditions facing the economy and companies, or the external effects on themselves of potentially inconsistent demands. For a thorough discussion on how the institutional framework determines the bargaining output in Brazil, see Arbache (2002).
} 
on the wage structure and wage dispersion. Second, the neo-liberal nature of the reforms and the pace of the changes. Brazil was a very closed economy as a result of the import substitution industrialization strategy pursued for several decades. In just a few years it turned from a protected, regulated, and predominantly Stated-owned economy to a relatively liberal trade regime, deregulated and privatized. This makes the Brazilian case an interesting natural experiment.

We employ comparable micro-data sets for selected years from 1988 to 1996 - which cover the pre and post-trade reform period - to investigate the impact of unions on wage dispersion and wage structure. Given the nature of the reforms and the pace of the changes, we could expect a sizeable response from unions. We show, however, that in general such a result does not apply, and unions increased their influence on the wage structure and wage dispersion, although there were relative wage changes according to thesectoral import penetration. Industries most affected by international competition faced a decrease in their relative wages, while industries least affected faced an increase in relative wages. Overall, however, the union wage dispersion increased as compared to nonunion wage, and the union wage mark-up increased as well. The important result is that trade liberalization may not suffice to restrain union power on wage set up.

The paper is organized as follows. Section 2 presents the basic theoretical background on unions and trade. Section 3 shows some indicators on Brazilian international trade and describes the data. Section 4 investigates the relationship between unions, trade, wage dispersion, and wagestructure, and estimates the union wage mark-up. Section 5 concludes.

\section{Theory and evidence on unions and trade}

The literature on unions and international trade shows that increasing imports and the removal of trade barriers have a negative impact on union wages (MacPherson and Stewart, 1990; Freeman and Katz, 1991; Driffill and van der Poeg, 1995; Gaston and Tefler, 1995). Cournot and DixitStiglitz type model s can be used to show that imports and exports influence union wages through the industry's product market. Greater imports 
(exports) increase (decrease) the product demand elasticity, reduce (increase) profits, and lead to wage concessions (gains) by unions. Freeman and Katz (1991), for example, use a monopoly union model framework to show that a larger price el asticity due to trade (and other factors) implies an inferior union wage-employment trade-off. Huizinga (1993) shows that in imperfectly competitive product markets, an increase in international competition is likely to increase the product demand elasticity and lead to wage concessions by unions. If trade keeps the elasticity unchanged, but shifts the demand curve downward, the union is also likely to lower wage demands. So, if international competition or other changes reduce the rents appropriated by the firm, it is also likely to reduce the rents enjoyed by workers. The greater the union-nonunion wage differential, the higher the response of union wages to changes in market conditions. In this approach, import liberal ization is likely to affect union wages more than those of their nonunion counterparts.

The nonunion sector is al so potentially affected by increasing openness through rent-sharing and union threat effects. However, because the nonunion labor market is more competitive, it is unlikely that trade liberalization impacts upon nonunion workers more than on union workers. Thus, international trade works as a disciplining device, and faced with negative shocks, unions are likely, ceteris paribus, to focus more on employment and less on wages. Nevertheless, the wage responses to changes in product demand are likely to depend on the bargaining framework, and on the structure of labor demand and supply. Differences in these fundamental aspects among countries may lead to differences in the responses of unions to trade liberalization.

The empirical literature al so finds that wages may increase rather than decrease with imports (Partridge, 1993; Blumenfeld and Partridge, 1996). It is argued that it may be due to unions' strategic behavior. There are at least two models that explain this outcome. Lawrence and Lawrence (1985) examine the hypothesis of "endgame bargaining". An industry facing increasing import competition is suggestive of economic decline, with reduced opportunity to invest in new capital and equipment. Therefore, it is unlikely that this industry can substitute capital for labor, and the union exploits this fact by trying to extract capital's quasi-rents. 
Conversely, an industry facing increasing exports may be encouraged to invest in equipment and new plant. In these circumstances, fearing that the industry can adopt more capital-intensive technologies, unions act strategically by moderating their wage demands. Therefore, there is a positive relationship between imports and wages, and a negative relationship between exports and wages.

Grossman (1984) examines the union wage response to increased international competition in a partial equilibrium model of monopoly union. Unions determine wage demands in a medium voter member framework. He assumes that union members are subject to seniority lay off, which has two offsetting impacts on union wages caused by increase in import competition. On the one hand, higher import competition reduces the probability of employment, which leads unions to focus on lower wages, since some of their members will have a higher probability of being laid off. On the other hand, increased import competition reduces unions employment and forces the least senior employee to belaid off. The "new" median voter will have a higher preference for wages than the "old" median voter. The weight of these two factors depends on the elasticity of labor demand, which depends on the industry technology and factor substitution possibilities. The outcome of these two forces will determine the response of unions to import competition. The net effect is ambiguous in general, but the model shows that in the case of a constant elasticity of labor demand, union wages are unresponsiveto international competition.

Although very interesting, thetheoretical literature does not shed light on the critical topic of the net effect of trade on the wage structure through the union channel. Since trade liberalization does not affect industries on the same way, the overall impact of unions on wages based on disaggregated industry level data may be ambiguous. This is, therefore, an empirical issue.

\section{Trade liberalization and data description}

Before we introduce the data, we providesome information on the Brazilian trade openness. Contrary to what occurred in many other developing 
countries in which trade reforms were gradually introduced and had a moderate impact (Adriamananjara and Nash, 1997), the change in trade policy in Brazil in between 1990 and 1993, along with the strong overvaluation of the local currency after the introduction of the Plano Real in mid-1994, seem to have been more radical. This is confirmed by the very rapid rise in the import penetration ratio in the manufacturing sector illustrated in Figure 1, and by the fall of the export intensity ratio, shown in Figure 2. There is a clear shift in the import pattern from 1990 onwards. By 1996, the import penetration ratio had reached 11.5 - more than twice the figure for 1990.

There are, however, large differences in import penetration by industry at the 2-digit level. The level of import penetration of Food, Furniture, and Wood industries, for example (the typical labor-intensive sectors), reached at most 5 percent of the apparent domestic demand in each industry. In contrast, industries such as Chemical, Electronic and Mechanic (the typical tradable and capital-intensive industries) experienced very large changes in import penetration (as much as from 8 percent to 29 percent). In regard to exports, there was a common pattern and all industries experienced a significant drop of the export intensity ratio in between 1992 and 1996. As a consequence, the imports rise is expected to have different impacts on wages and employment within and between industries.

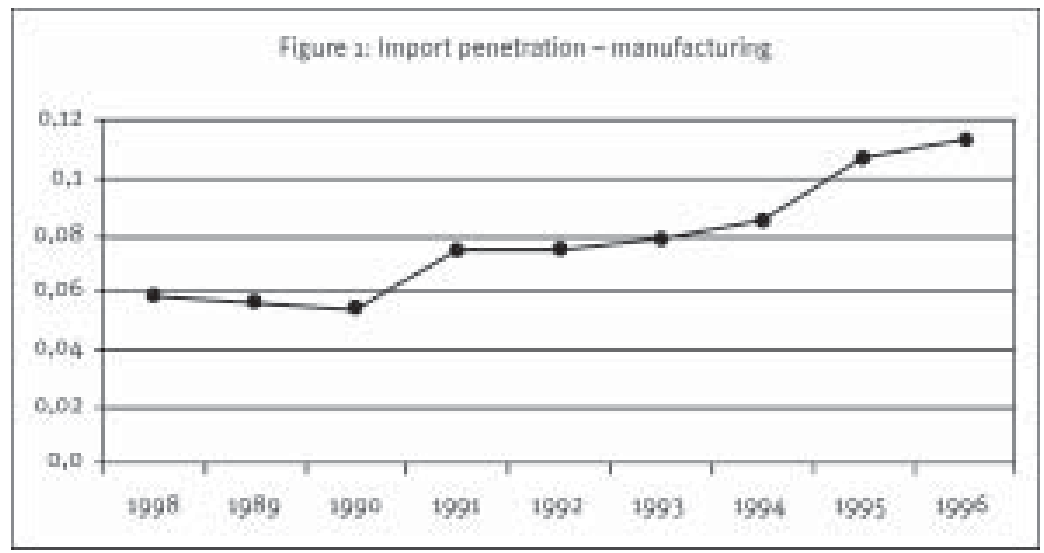




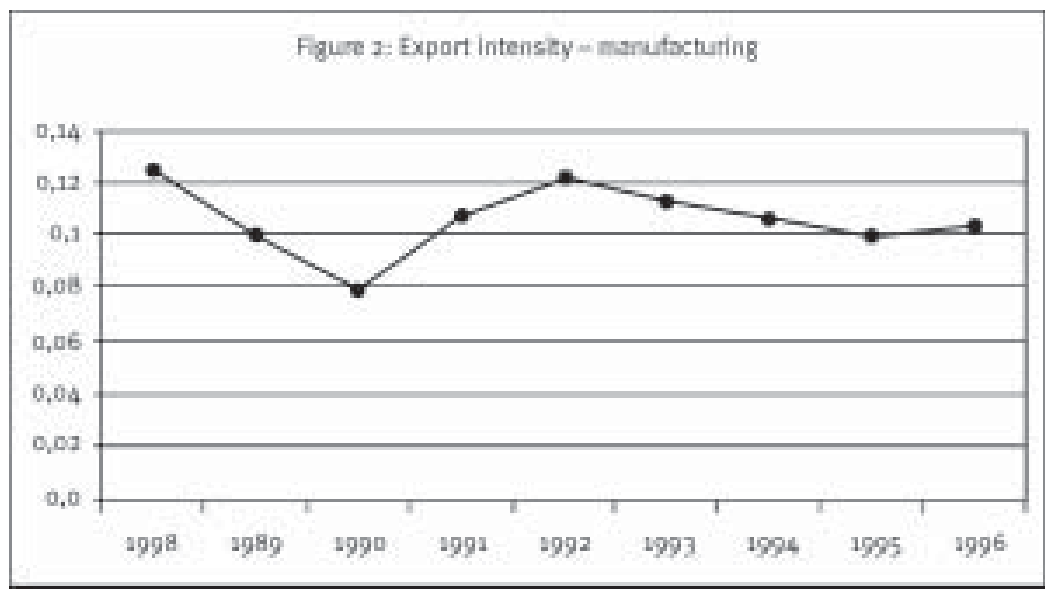

In this paper, we use cross-sectional micro-data from the National Household Surveys (PNAD), published by the Brazilian Institute of Geography and Statistics (IBGE), for 1988, 1992, and 1996. These years cover the period before, during and after the trade liberalization. The three samples consist of a total of 21,798 individuals, from which 7,718 are unionized. The concept of unionization in PNAD is union membership. The survey asks the individual whether he/ she is a member of a union. The samples we analyze are the result of the following filter: active individuals, employees, males, between the ages of 18 and 65 , and affiliated to the manufacturing sector. The hourly wages are deflated by the CPI of September 1998. The study focuses on the manufacturing sector because of data limitations regarding international trade for other sectors. However, manufacturing accounts for the largest share of the Brazilian international trade (on average, more than 65 percent of total exports, and an even larger proportion of total imports, excluding crude oil).

Table 1 shows the means and standard deviation for a number of variables for union and nonunion workers. Union workers are older, have more accumulated human capital - measured by education and experience-, have higher probability of being white and head of family, and nearly 100 percent have a formal labor contract ( given by the possession of work- 
card). ${ }^{2}$ There is a noticeable shift on the average education of union workers from 1988 to 1996. While it increased 8 percent for union, it increased only 2 percent for nonunion workers. The raw union-nonunion wage differential increased monotonical ly overtime. In 1988, it was 22.5 percent. In 1992, it had risen 30.5 percent, reaching to 35.4 percent in 1996. This suggests a strong union power, not only to keep, but also to enlarge the wage premium, even after the trade liberalization. Consistent with the findings of Arbache (1999, 2002), the standard deviation of union wages is always higher than that of nonunion wages, which contrasts with the pervasive empirical evidence supporting the standardization of wage rate policy (Freeman, 1980). It seems that even the market-oriented economic reforms introduced in the beginning of the 1990s have not changed the pattern of thestructure of wage bargaining in Brazil. Although thestandard deviation of wages decreases from 1988 to 1996 for both groups, the nonunion workers experience a relatively higher compression of wage dispersion, confirming the union power to keep unchanged the wage structure.

\footnotetext{
${ }^{2}$ The work-card variable is related to the status of the labor contract. It captures the effects of labor legislation on wage determination. Private employers must register each of their workers in the form of signing in the very beginning of a labor contract a booklet held by the worker called "work-card". It can be interpreted as a formal labor contract agreement, which entitles the employed worker to all rights, guarantees and benefits provided by the Labor Code. Experience is constructed in the following manner: age-years of study- 6 .
} 


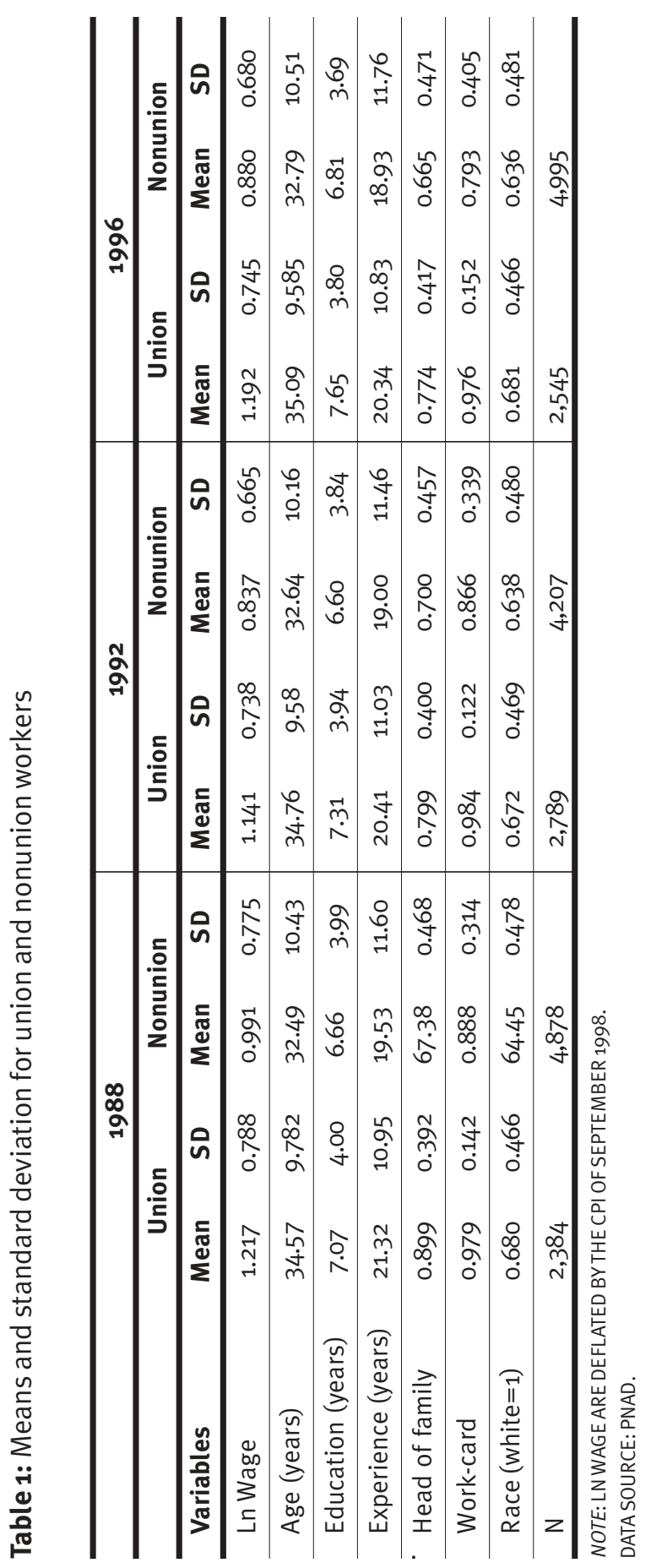




\section{Unions, trade, wage dispersion and wage structure}

\subsection{Wage dispersion}

In order to investigate the impact of unions on the wage dispersion before and after the trade liberalization, we look at the union and nonunion wage standard deviation. The first, third and fifth columns of Table 2 show the unconditional and conditional standard deviation of log hourly real wages of union and nonunion workers for before and after the implementation of the trade reform. Two features are apparent.

First, as seen before, the wage dispersion in the union sector is al ways higher than in the nonunion sector. This result - identified by Arbache (1999, 2002) and Arbache and Carneiro (1999) as associated to the strong rent-seeking effect al lowed by the structure of wage bargaining in Brazil - stresses that even in a more competitive environment, collective bargaining is still a pervasive phenomenon influencing the wage structure and wage determination. Considering that union power tends to be weakened by a tighter labor market, as suggested by Cournot type models, and supported by the empirical literature (MacPherson and Stewart, 1990; Freeman and Katz, 1991; Blumenfeld and Partridge, 1996), one could predict that the degree of wage dispersion in the union sector would decrease and probably converge towards that of the nonunion wage sector. Second, the conditional standard deviation of wages is significantly smaller than the unconditional standard deviation. This implies that the control variables in the wage equations play an important role in the explanation of wage dispersion.

In order to assess how the economic reforms have affected wage dispersion in the union vis-à-vis the nonunion sectors overtime, we cal culate the ratio of standard deviation - the SD -ratio -, as follows:

$$
S D-\text { ratio }=\frac{S D^{U}}{S D^{N}},
$$

where $S D^{U}$ is the standard deviation of union wages, and $S D^{N}$ is the standard deviation of nonunion wages. This ratio provides a raw 
assessment of the relative standard deviation. According to the theory of unions and international competition, one could expect that the market-oriented economic reforms would cause this ratio to converge to a figure lower than 1 , since the union wage would be more responsive to the more competitive labor market. This, however, does not apply. Consider the conditional SD -ratios (columns II, IV, and VI, panel 2, Table 2). In 1988, it was 1.026; in 1992 and 1996, it increased to 1.19 and 1.20, respectively, levels much higher than that prevailing before the trade reform! This result is unexpected, since it suggests that unions could amplify the relative wage dispersion in a more competitive environment.

Table 2: Standard deviation of log hourly wages and SD-ratio

\begin{tabular}{|c|c|c|c|c|c|c|}
\hline & \multicolumn{2}{|l|}{1988} & \multicolumn{2}{|c|}{1992} & \multicolumn{2}{|c|}{1996} \\
\hline & $\mathrm{SD}(\mathrm{I})$ & SD-ratio(II) & $\mathrm{SD}(\mathrm{III})$ & SD-ratio(IV) & $\mathrm{SD}(\mathrm{V})$ & SD-ratio $(\mathrm{VI})$ \\
\hline \multicolumn{7}{|c|}{ 1. Unconditional standard deviation } \\
\hline All & 0.786 & & 0.711 & & 0.717 & \\
\hline Union & 0.788 & 1.017 & 0.738 & 1.110 & 0.745 & 1.095 \\
\hline Nonunion & 0.775 & & 0.665 & & 0.680 & \\
\hline \multicolumn{7}{|c|}{ 2. Conditional standard deviation* } \\
\hline All & 0.581 & & 0.468 & & 0.468 & \\
\hline Union & 0.582 & 1.026 & 0.499 & 1.188 & 0.506 & 1.198 \\
\hline Nonunion & 0.567 & & 0.419 & & 0.422 & \\
\hline
\end{tabular}

NOTE: $\left(^{*}\right)$ CONDITIONAL STANDARD DEVIATION OF PREDICTED WAGES. VARIABLES IN THE WAGE EQUATION ARE METROPOLITAN AREA, URBAN-RURAL, RACE, HEAD OF FAMILY, WORK-CARD, EDUCATION, EXPERIENCE, EXPERIENCE SQUARED, FIVE REGION DUMMIES, AND 21 INDUSTRY DUMMIES. SD-RATIO IS SD UNION/SD NONUNION. DATA SOURCE: PNAD.

The wage variance of union and nonunion workers is further examined by estimating the dispersion of the inter-industry wage differentials. The strategy we adopt to estimate the inter-industry differentials is through the approach proposed by Haisken-DeN ew and Schmidt (1997), which improves the standard procedure popularized by Krueger and 
Summers (1988). The wage equations are estimated by OLS in the following form:

$$
\ln w_{i j}=\alpha+\beta X_{i}+\varphi Z_{j}+\varepsilon_{i j}
$$

where $\operatorname{lnw}_{\mathrm{ij}}$ is the natural logarithm of the hourly real wage of worker $\mathrm{i}$ in industry $j, X_{i}$ is a vector of personal characteristics, $Z_{j}$ is a vector of industry dummies which includes all industries, is the intercept term, $\varepsilon_{i j}$ is a random disturbance term reflecting unobserved characteristics and the inherent randomness of earnings statistics, and and are the vectors of parameters to be estimated. Since in this model the cross-product matrix of the regressors is not of full rank, a linear restriction is imposed on the $\mathrm{s}$ as follows,

where $n_{j}$ is the employment share in industry $j$. The reported coefficients can then be interpreted as the proportionate difference in wages between a worker in industry $j$ and the average worker from the whole of manufacturing industry, after controlling for the other factors which determine wages. The formulation given by (2) and (3) provides both economically sensi ble coefficients and their correct standard errors in a single regression step (see Haisken-DeN ew and Schmidt, 1997, for further details). The inter-industry wage dispersion is computed in the following way:

$$
S D(\varphi)=\sqrt{n^{\prime}\left(\bar{H}\left(\varphi_{j}\right)\right) \varphi_{j}-n^{\prime} \bar{D}\left(V\left(\varphi_{j}\right)\right)} .
$$

$S D(\varphi)$ gives the weighted and adjusted standard deviation of coefficients, transforms a column vector into a diagonal matrix whose diagonal is given by the column vector itself, $\bar{D}$ denotes the column vector formed by the diagonal elements of a matrix, and $V$ is the variance-covariance matrix. 
The bottom of Table 3 shows that the weighted and adjusted standard deviation of the inter-industry wage premia of union wages is always larger than that of nonunion wages, confirming the previous findings. After the introduction of the trade reform, the inter-industry wage premia dispersion starts to converge towards zero in both groups, but in a much higher pace in the union sector. ${ }^{3}$ Although the union wage dispersion is al ways higher, in 1996 the gap was largely reduced. This can be explained by the increased importance of control variables on the wage determination of union workers. ${ }^{4}$ These results imply that the larger raw union wage dispersion can be seen as an outcome of the individual characteristics on wages.

${ }^{3}$ While the standard deviation of the wage premia of nonunion workers in 1996 is 30 percent lower than that for 1988, the standard deviation of the union wage premia decreased 38 percent in the same period.

${ }_{4}^{4}$ In 1988, the inclusion of control variables in wage equations could reduce 44 percent and 50 percent the dispersion of the union and nonunion wage premia, respectively. In 1996, however, the control variables reduced the wage premia dispersion in about 56 percent and 54 percent, respectively, for union and nonunion workers. 
Table 3: Union and nonunion inter-industry wage differentials

\begin{tabular}{|c|c|c|c|c|c|c|}
\hline \multicolumn{3}{|c|}{1988} & \multicolumn{2}{|c|}{1992} & \multicolumn{2}{|c|}{1996} \\
\hline Industry & Union & Nonunion & Union & Nonunion & Union & Nonunion \\
\hline Non-Metallic & -0.048 & -0.046 & 0.045 & $-0.059^{\star}$ & -0.087 & -0.028 \\
\hline Metallurgic & 0.019 & -0.008 & -0.006 & $0.052^{*}$ & 0.008 & $0.061^{*}$ \\
\hline Mechanic & 0.066 & $0.125^{\star}$ & 0.019 & $0.093^{*}$ & 0.052 & 0.052 \\
\hline Electro-Electronics & $0.169^{\star}$ & $0.160^{\star}$ & $0.115^{*}$ & $0.051^{\star}$ & 0.010 & $0.106^{\star}$ \\
\hline Transport materials & $0.204^{\star}$ & $0.192^{\star}$ & $0.163^{*}$ & $0.247^{\star}$ & $0.146^{\star}$ & $0.164^{\star}$ \\
\hline Wood & $-0.163^{\star}$ & $-0.121^{\star}$ & $-0.166^{\star}$ & $-0.150^{\star}$ & -0.047 & $-0.138^{\star}$ \\
\hline Furniture & $-0.256^{\star}$ & $-0.177^{\star}$ & $-0.244^{\star}$ & $-0.168^{\star}$ & $-0.278^{\star}$ & -0.051 \\
\hline Paper & -0.035 & $0.134^{*}$ & $0.111^{*}$ & $0.153^{*}$ & 0.019 & 0.036 \\
\hline Rubber & 0.136 & 0.054 & 0.113 & -0.000 & $0.337^{\star}$ & 0.064 \\
\hline Leather & -0.107 & $-0.226^{\star}$ & $-0.341^{\star}$ & -0.095 & $-0.386^{\star}$ & -0.067 \\
\hline Chemical & $0.348^{\star}$ & $0.120^{\star}$ & $0.297^{\star}$ & $0.128^{\star}$ & $0.144^{\star}$ & 0.033 \\
\hline Pharmaceutical & $0.175^{\star}$ & $0.223^{*}$ & $0.281^{\star}$ & 0.137 & $0.226^{*}$ & $0.459^{\star}$ \\
\hline Perfume & 0.107 & -0.128 & 0.162 & 0.005 & 0.089 & -0.029 \\
\hline Plastics & -0.099 & 0.081 & -0.026 & 0.041 & $-0.096^{*}$ & -0.047 \\
\hline Textiles & $-0.088^{\star}$ & -0.006 & $-0.121^{\star}$ & 0.022 & $-0.123^{\star}$ & -0.006 \\
\hline Apparel & $-0.215^{\star}$ & $-0.178^{\star}$ & $-0.194^{*}$ & $-0.092^{\star}$ & $-0.205^{\star}$ & $-0.116^{\star}$ \\
\hline Food & $-0.226^{\star}$ & $-0.122^{\star}$ & $-0.128^{\star}$ & $-0.094^{\star}$ & $-0.084^{*}$ & $-0.037^{\star}$ \\
\hline Beverage & $-0.208^{\star}$ & $-0.148^{\star}$ & $-0.171^{*}$ & -0.035 & 0.006 & -0.053 \\
\hline Tobacco & 0.119 & 0.041 & 0.093 & $0.362^{\star}$ & 0.006 & 0.125 \\
\hline Publishing & $-0.192^{\star}$ & -0.068 & $-0.144^{\star}$ & $-0.078^{\star}$ & 0.013 & -0.025 \\
\hline Others & -0.082 & -0.027 & $-0.208^{\star}$ & -0.024 & -0.005 & -0.066 \\
\hline $\mathrm{R}^{2}$ & 0.504 & 0.479 & 0.416 & 0.369 & 0.443 & 0.368 \\
\hline F-test & 87.57 & 152.81 & 71.52 & 84.53 & 66.65 & 96.16 \\
\hline $\mathrm{N}$ & 2,384 & 4,878 & 2,810 & 4,261 & 2,545 & 4,995 \\
\hline $\begin{array}{l}\text { Weighted and } \\
\text { adjusted SD }\end{array}$ & $\begin{array}{c}0.159 \\
(0.286)\end{array}$ & $\begin{array}{c}0.118 \\
(0.239)\end{array}$ & $\begin{array}{c}0.144 \\
(0.241)\end{array}$ & $\begin{array}{c}0.102 \\
(0.189)\end{array}$ & $\begin{array}{c}0.099 \\
(0.225)\end{array}$ & $\begin{array}{c}0.082 \\
(0.180)\end{array}$ \\
\hline
\end{tabular}

NOTES: OTHER REGRESSORS IN THE WAGE EQUATIONS ARE METROPOLITAN AREA RESIDENCE, URBAN-RURAL, RACE, HEAD OF FAMILY, WORK-CARD, EDUCATION, EXPERIENCE, EXPERIENCE SQUARE, AND FIVE REGION DUMMIES. (*) SIGNIFICANT AT THE 5 PERCENT LEVEL. THE WEIGHTED AND ADJUSTED STANDARD DEVIATION OF THE WAGE PREMIA IN PARENTHESES ARE THOSE OF NOT CONTROLLED WAGES.

DATA SOURCE: PNAD. 


\subsection{Wage dispersion and international competition}

An obvious problem with the above figures is the likely aggregation-effect. Unions in industries facing different levels of international competition may behave rather differently. Therefore, we adopt a disaggregated investigation of the SD-ratio by industry level. We proceed in a two-part analysis. In step 1 we classify the 2-digit industries in three groups according to the magnitude of the change in level of import penetration from 1988 to 1996 (i.e. level of import penetration in 1996 minus level of import penetration in 1988). In step 2 we calculate the SD-ratio for each of the three groups of industries. Since unions in industries facing higher international competition tend to have reduced their bargaining power, we expect to find the SD-ratio of high import penetration industries to fluctuate around 1 , and the SD -ratio of low import penetration industries to be somewhat higher than 1 .

The industry classification in each of the three industrial groups is reported in Table 4. Note that this classification may reflect the heterogeneity of the trade policies for each industry regarding tariff and nontariff barriers, and international competitiveness of each industry. The weighted mean from the high import penetration industry group is 2.3 times and 5.4 times bigger than that from medium and low import penetration industry groups, respectively, which is an evidence of the quite different impact of the trade liberalization across industries. As a consequence, we expect to find different responses from unions in each industry group to the international competition. 
Table 4: Change in import penetration level - 1988-1996 - percentage points

\begin{tabular}{|c|c|c|c|c|c|}
\hline & High & & Medium & & Low \\
\hline Mechanics & 16.4 & Paper & $4 \cdot 5$ & Wood & 0.9 \\
\hline Electronics & 18.6 & Publishing & 4.5 & Furniture & 0.9 \\
\hline Textiles & 13 & Pharmaceutical & 4.5 & Non-metallic & 1.7 \\
\hline \multirow[t]{4}{*}{ Other } & 12.6 & Chemical & 7.4 & Plastics & 3.3 \\
\hline & & Perfume & $4 \cdot 5$ & Metallurgic & 3.5 \\
\hline & & Transportation & 7.8 & Food & 3.5 \\
\hline & & Apparel & 8.0 & Rubber & 3.9 \\
\hline Weighted mean & $15 \cdot 5$ & Weighted mean & 6.7 & Weighted mean & 2.9 \\
\hline
\end{tabular}

NOTE: THE CRITERION IS DIVIDING THE 2-DIGIT INDUSTRIES IN THREE GROUPS IN THE FOLLOWING WAY: o TO 4 PERCENTAGE POINTS CHANGE IN IMPORT PENETRATION; 4.1 TO 8 PERCENTAGE POINTS CHANGE IN IMPORT PENETRATION; AND 8.1 OR MORE PERCENTAGE POINTS CHANGE IN IMPORT PENETRATION. THE WEIGHTED MEANS ARE BASED ON THE INDUSTRY EMPLOYMENT SHARE IN 1992.

DATA SOURCE: PNAD.

Table 5 reports the SD -ratio for each of the three industry groups and shows distinct responses according to the change in import penetration. The high import penetration industries had a SD-ratio of 0.97 in 1988, but experience a modest increase in 1992 and 1996. The SD-ratio of the medium import penetration group - which was al ready high in 1988 (1.13) - seems to be hit by the trade reforms, dropping to 1.075 in 1996. The SD-ratio of thelow import penetration industries increases to a quite high level, suggesting a strong union ability to take advantage of the relatively more comfortable situation of these industries vis-à-vis the manufacturing as a whole. Obviously, this is also a result of the relatively higher ability of these industries to acquiesce to wage demands, which allows unions to enhance their relative power as compared to unions in industries more affected by international competition. 
Table 5: Conditional standard deviation of log hourly wages by industry groups according to the change in import penetration level and SD ratio

\begin{tabular}{|c|c|c|c|c|c|c|}
\hline \multicolumn{3}{|c|}{1988} & \multicolumn{2}{|c|}{1992} & \multicolumn{2}{|c|}{1996} \\
\hline & SD & SD-ratio & SD & SD-ratio & SD & SD-ratio \\
\hline \multicolumn{7}{|c|}{ 1. High import penetration industries } \\
\hline All & 0.605 & & 0.480 & & 0.454 & \\
\hline Union & 0.598 & 0.973 & 0.493 & 1.044 & 0.479 & 1.079 \\
\hline Nonunion & 0.615 & & 0.472 & & 0.443 & \\
\hline $\mathrm{n}(\mathrm{All})$ & 1,500 & & 1,268 & & 1,310 & \\
\hline \multicolumn{7}{|c|}{ 2. Medium import penetration industries } \\
\hline All & 0.626 & & 0.503 & & 0.513 & \\
\hline Union & 0.672 & 1.131 & 0.523 & 1.154 & 0.514 & 1.075 \\
\hline Nonunion & 0.594 & & 0.453 & & 0.478 & \\
\hline $\mathrm{n}(\mathrm{All})$ & 2,085 & & 2,051 & & 2,066 & \\
\hline \multicolumn{7}{|c|}{ 3. Low import penetration industries } \\
\hline All & 0.487 & & 0.410 & & 0.426 & \\
\hline Union & 0.508 & 1.105 & 0.464 & 1.313 & 0.495 & 1.341 \\
\hline Nonunion & 0.459 & & 0.354 & & 0.369 & \\
\hline n (All) & 3,350 & & 3,310 & & 3,807 & \\
\hline
\end{tabular}

NOTE:THE 2-DIGIT INDUSTRY IS CLASSIFIED IN THREE GROUPS ACCORDING TO CHANGES IN IMPORT PENETRATION IN 1988-1996. FOR DETAILS, SEE TABLE 4. SDS ARE PREDICTED CONDITIONAL WAGES. VARIABLES IN THE WAGE EQUATION ARE METROPOLITAN AREA RESIDENCE, URBAN-RURAL, RACE, HEAD OF FAMILY, WORK-CARD, EDUCATION, EXPERIENCE, EXPERIENCE SQUARE, FIVE REGION DUMMIES, AND INDUSTRY DUMMIES. SD-RATIO IS SD UNION/SD NONUNION. DATA SOURCE: PNAD.

\subsection{Wage structure}

Our results highlight an important feature in the analysis of the effects of trade liberalization on wages, namely, the different impacts competition may cause in each industry and their effects on union behavior. Unions in the low import penetration industries are likely to weigh wage gains highly relative to employment gains, possibly causing an increase in their relative wages. However, unions in industries facing threats of plant shutdowns the high and medium import penetration groups - are willing to offer 
wage concessions to save jobs. As a consequence, one may predict that there may have a change in the structure of wages according to the changes in the relative pow er of unions. The aggregate effect on the wage structure, however, will depend on the net effect of these contrary forces.

In order to assess the above prediction, we examine the changing on the wage premia of the three industry groups. We calculate the weighted average inter-industry wage premia change from 1988 to 1996 for each industry group. ${ }^{5}$ We expect to find that the relative wage premia of low import penetration industries are better off and vice-versa. Also, we expect to find that unions in industries least affected by import competition have a more aggressive strategy in favor of wages, while unions in the most affected industries may be forced to accept wage concessions.

Table 6 shows that workers in low import penetration industries enjoy an average increase of wage premia, while workers in the high import penetration industries experience an average decrease of industry wage premia. The analysis by union status shows that union and nonunion workers in the low import penetration industries have an average wage premia improvement of 4 percent and 6 percent, respectively. A different picture is seen in the medium import penetration group. Union workers experience a 3.3 percent decrease, while the nonunion workers experience a wage inertia. Union workers wages in the high import penetration industries, however, were more severely affected by import competition, experiencing 5.4 percent wage premia decrease. The nonunion workers' wages in this sector were unaffected. The fact that the nonunion wages in the high and medium industry groups were barely affected suggests that their wages were al ready set up in a competitive framework. On the other hand, in the case of the low import penetration group, the nonunion workers' wages seem to have been positively affected by the wage increase of the union wages. ${ }^{6}$

${ }_{5}$ The inter-industry wage premia are from Table 3.

${ }^{6}$ Raw calculations show that real wages of high import penetration workers decreased 10.3 percent between 1988 and 1996; wages of workers in the medium import penetration decreased 7.6 percent; and the wages in low import penetration industries dropped 5 percent. 
The empirical evidence on the higher responsiveness of union wages to trade (MacPherson and Stewart, 1990; Freeman and Katz, 1991; Gaston and Tefler, 1995) is observed, in the case of Brazil, only in the industries most affected by international competition. Unions in industries least affected by trade ampl ify, rather decrease their relativewages. This suggests a change on the relative power of unions within manufacturing and, therefore, on the wage structure, highlighting how distinct are unions' reactions to economic openness.

Table 6: Weighted average wage premia change by import penetration 1988-1996

\begin{tabular}{ll|c|c}
\hline & High & Medium & Low \\
\hline Union & -0.053 & -0.033 & 0.039 \\
\hline Non-union & 0.004 & 0.000 & 0.058 \\
\hline
\end{tabular}

NOTESFOR DETAILS ON IMPORT PENETRATION GROUPS, SEE TABLE 4. INTER-INDUSTRY WAGE PREMIA AREAS ESTIMATED IN TABLE 3. WEIGHTS ARE THE INDUSTRY EMPLOYMENT SHARE IN 1992.

DATA SOURCE: PNAD.

We assess the wage structure changes by calculating the Pearson correlation coefficient of inter-industry wage differentials for union and nonunion workers. We expect to find changes in the wage structure of union workers due to the union power changes observed above. Table 7 shows that the union wage correlation experiences a large reduction overtime, suggesting changes on the union wage structure. In the case of nonunion workers, the correlation remained almost unaltered between 1988 and 1996, supporting the evidence that their wages were already been determined in a competitive basis. 
Table 7: Pearson correlation of inter-industry wage differentials

\begin{tabular}{lc|c|c}
\hline & $\mathbf{1 9 8 8 - 1 9 9 2}$ & $\mathbf{1 9 9 2 - 1 9 9 6}$ & $\mathbf{1 9 8 8 - 1 9 9 6}$ \\
\hline Union wages & 0.8 & 0.75 & 0.61 \\
\hline Non-union wages & 0.56 & 0.54 & 0.61 \\
\hline
\end{tabular}

NOTE: INTER-INDUSTRY WAGE DIFFERENTIALS ARE FROM TABLE 3 . ALL FIGURES ARE STATISCALLY SIGNIFICANT AT THE $5 \%$ LEVEL.

DATA SOURCE: PNAD.

\section{Conclusion}

This paper tracked the influence of unions on the wage dispersion and wage structure in Brazil before and after the introduction of trade liberalization in the beginning of the 1990s. We show not only a union wage change between industry groups - according with the degree of import penetration - but also within industry groups among union and nonunion workers. Unions in the sectors least affected by import penetration took advantage of the relatively more comfortable environment to improvetheir relative wages, while unions in sectors most affected by international competition were more responsive to trade openness and were willing to accept decreases in relative wages. As a result, there was a change in the dispersion and structure of wages according to the change in the relative power of unions. The effects coming from unions in low import penetration industries dominated the effects coming from unions in industries most affected by international competition. An important implication of our results is that openness to international trade does not always decrease union bargaining power, at least in the short- to mid-term period. This outcome seems to be associated to the bargaining framework prevailing in the Brazilian labor market, which is strongly conducive to rent-seeking behavior. 


\section{References}

ADRIAMANANJARA, S. and NASH, J. (1997), "Have Trade Policy Reforms Led to Greater Openness in Developing Countries?", Policy Research Working Paper No. 1730, Washington DC: World Bank.

AMADEO, E.J. (1993), “Do Relative Wages Move Together with Relative Prices?", Revista Brasileira de Economia, 47: 33-52.

Amadeo, E. J. (1994), 'Bargaining Power, Mark-up, and Wage Differentials in Brazil', Cambridge J ournal of Economics, 18: 313-322.

ARBACHE, J. S. (1999), "Do Unions Always Decrease Wage Dispersion? The Case of Brazilian Manufacturing", Journal of Labor Research, 20: 425-436.

ARBACHE, J. S. (2002), "Unions and the labor market in Brazil", B razil Jobs R eport, Volume II, Washington, DC: The World Bank.

ARBACHE, J. S. and CARNEIRO, F.G. (1999), "Unions and Wage Differentials", W orld D evel opment, 27: 1875-1883.

BLUMENFELD, S. B. and PARTRIDGE, M.D. (1996), "The Long-Run and ShortRun Impacts of Global Competition on U.S. Union Wages", Journal of Labor Research, 17: 149-171.
CALMFORS, L. and DRIFFILL, J. (1988), "Bargaining Structure, Corporatism and Macroeconomic Performance", Economic Policy, 6:13-61.

CARNEIRO, F. G. (1999), “Insider Power in Wage Determination: Evidence from Brazilian Data", Review of Development Economics, 3: 155-169.

DRIFFILL, J. and VAN DER POEG, F. (1995), "Trade Liberalisation with Imperfect Competition in Goods and Labour Markets", Scandinavian Journal of Economics, 97: 223-243.

FORTIN, N. M. and LEMIEUX T. (1997), "Institutional Changes and Rising Wage Inequality: Is There a Linkage?", Journal of Economic Perspectives, 11: 75-96.

FREEMAN, R. (1980), “Unionism and the Dispersion of Wages", Industrial and Labor Relations R eview, 34: 3-23.

FREEMAN, R. B. and KATZ, L. F. (1991), "Industrial Wage and Employment Determination in an Open Economy", in J. M. Abowd and R. B. Freeman (edits.), Immigration, Trade, and the Labor Market, Chicago: University of Chicago Press.

GASTON, N. and TREFLER, D. (1995), "Union Wage Sensitivity to Trade and Protection: Theory and Evidence", J ournal of International Economics, 39: 1-25. 
GOSLING, A. and MACHIN, S. (1995), "Trade Unions and the Dispersion of Earnings in British Establishments, 1980-90", Oxford Bulletin of Economics and Statistics, 57: 167-184.

GROSSMAN, G. M. (1984), "International Competition and the Unionized Sector", Canadian Journal of Economics, 17: 541-556.

HAISKEN-DENEW, J. P. and SCHMIDT, C.M. (1997), "Inter-Industry and InterRegion Differentials: Mechanics and Interpretation", Review of Economics and Statistics, 79: 516-521.

HUIZINGA, H. (1993), "International Market Integration and Union Wage Bargain', Scandinavian Journal of Economics, 95: 249-255.

KRUEGER, A and SUMMERS, L. (1988), "Efficiency Wages and the Inter-Industry Wage Structure", Econometrica, 56: 159193.

LAWRENCE, C. and LAWRENCE, R. Z. (1985), "Manufacturing Wage Dispersion: an Endgame Interpretation", Brooking Papers on Economic A ctivity, 1: 47106.

MACPHERSON, D. A. and STEWART, J. B. (1990), "The Effect of International Competition on Union and Nonunion Wages", Industrial and Labor Relations Review, 43: 435-446.
PARTRIDGE, M. (1993), "Technology, International Competitiveness, and Union Behaviour", Journal of Labor Research, 14: 131-149.

PEOPLES, J. (1998), “Deregulation and the Labor Market", Journal of Economic Perspectives, 12: 111-130.

STEWART, M. B. (1991), “Union Wage Differentials in the Face of Changes in the Economic and Legal Environment", Economica, 58: 155-172. 